Jovana Mihailovic ${ }^{1}$

Vip mobile d.o.o., Belgrade, Serbia

\title{
The Future of Mobile Operators - New Business Models
}

DOI: 10.7595/management.fon.2018.0033

Abstract:

Research Question: This paper investigated business model innovation in telecommunication industry by analysing open business models that operators can implement to innovate and stay competitive in the market. Motivation: The study tends to cover all strategically important aspects for mobile operators present in literature - from telecommunications market analysis (ITU, 2017; Sujata et al., 2015), the importance of business model innovation (Ghezzi, Cortimiglia \& Franc, 2015) to collaboration models that raise innovation activities (Xu \& Chen, 2015; Dittrich \& Duysters, 2007; Weiblen \& Chesbrough, 2015) and to complement them with examples from practice. Idea: The aim of this paper is to analyse open business models and collaboration strategies operators have with partners and to show that business model innovation in telecommunication industry is as important as technological innovation. Data: Research was conducted by analyzing various studies, reports, reviews, books, white papers and articles. Tools: To answer the research question, we used statistical data published by respected bodies - ITU, Eurostat, Ratel as well as from leading vendors in telecommunication industry Cisco and Ericsson and leading mobile operators such as Telekom Austria, Telenor, Vodafone. Findings: The study highlights the rising importance of business model innovation and proposes open business models operators can implement to increase internal innovation activities. Contribution: The study complements the open innovation literature, especially in the Serbian market where no similar analysis was performed. The findings of this study can help manages and directors refine internal innovation processes and propose collaboration models for their company.

Keywords: Mobile operators, data traffic, innovation, business model, startups

JEL Classification: L22, L24, L96, M13, O31

\section{Introduction}

The development of mobile communications has drastically influenced people's lives. Each new release resulted in faster, higher bandwidth and more intelligent network. The terms Internet of things, virtual reality, artificial intelligence, big data, machine learning are all used in the context of digitalisation. It is a phenomenon which affects private, professional, and business spheres. Companies in the telecommunications sector are undergoing a fundamental shift to adapt to a digital world and have been developing from telephony service providers into data companies.

By being the 'backbone' of digitalisation, mobile operators become infrastructure providers. This significantly impacts their income since they went from service providers (offering voice and messaging services) to data package distributors. The Telecom operators had to painfully experience the disruptive power of OTT (Over The Top) services. The traditional sources of their income are showing signs of becoming obsolete (Sujata et al., 2015). Messaging platforms such as WhatsApp, Viber, Skype, Facebook Messenger and many others, have drastically decreased the voice traffic and messaging services.

On the other hand, mobile operators are uniquely positioned to create additional value across a range of industries and to become end-to-end service providers. Operators are connecting more and more to the digital lifestyle of their customers as they move from selling gigabytes to selling services and applicationscentric benefits (Allot, 2014). Nowadays mobile operators offer OTT services like music and video streaming 
services, cloud storage, location-based services. These services are provided by the operator itself or, more commonly, through different kinds of partnerships (BEREC, 2016). In emerging markets today there are many opportunities for mobile operators and startups to collaborate (Bayen \& Ajadi, 2017).

Companies commercialise new ideas and technologies through their business models (Chesbrough, 2010). Firms should consider changing their learning approaches over time to successfully renew their business models (Foss \& Saebi, 2016). Corporate business model transformation is defined as "a change in the perceived logic of how value is created by the corporation" (Aspara, Lamberg, Laukia \& Tikkanen, 2013). Open innovation is the use of purposive inflows and outflows of knowledge to accelerate internal innovation, and expand the markets for external use of innovation, respectively. This paradigm assumes that firms can and should use external ideas as well as internal ideas, and internal and external paths to market, as they look to advance their technology (Chesbrough, 2006). Access to external sources of knowledge enables new combinations of technologies and therefore, contributes to the innovation performance of firms (Cheng \& Huizingh, 2014). Companies wishing to engage in open innovation must (at least partly) re-organise their business models as to accommodate their open innovation strategies and to subsequently enhance innovative performance (Saebi \& Foss, 2014).

Mobile operators need a new business model that would incorporate their strategic objectives and targets. The goal of this paper is to show that, for mobile operators, a business model innovation is becoming as significant as technological innovation. The open business model is analysed as a possible model operators can use to enforce internal innovation and expand their portfolio. The research is explored by means of questions:

1. How is telecommunication market changing, how does it impact operators and how do they respond to it?

2. Which forms of partnerships do operators create with external organizations?

3. How does the digitalisation trend influence the Serbian telecommunication market and how do mobile operators respond to digitalisation trend compared to other developed countries?

The paper is structured in the following way. In the second chapter a literature review on new business models in the telecommunication market is presented. The research methodology is described in chapter three. The telecommunication market trend and strategy of mobile operators are analysed in chapter four. Chapter five describes possible collaboration models between operators and external partners. Each model is followed by an example from practice. Chapter six analyses the situation on the telecommunication market in Serbia, and how operators deal with it. Chapter seven presents results and discussion; chapter eight concludes the work.

\section{Literature Review}

The telecommunications market is constantly evolving with increasing demand for faster data speeds, ongoing external regulatory and competitive pressures and changing societal expectations (Vodafone, 2017). Operators are challenged to innovate in both technological and product segments (Asimakopoulos \& Whalley, 2017). The survival of telecom service providers has become very demanding as the telecom market is now highly saturated and on the verge of big changes (Yang, Trimi \& Lee, 2016). Driven by a digital transformation of the telecom business, operators need to evolve and adjust their portfolios. One of the great challenges operators face is how to compete with other OTT providers (Wang, Lai \& Chang, 2016). The impact of OTT service providers on the telecommunication market, consumer trends toward the adoption of OTT services and how they influence operator revenues were analysed by several authors (Sujata et al., 2015; Lutilsky \& Ivic, 2016; Gerpott \& Meinert, 2016).

Monitor Deloitte predicted four possible scenarios that could happen to mobile operators in the future depending on infrastructure and services ownership. In the first scenario operators possess the whole system from technological assets to end to end customer services. In the second scenario, mobile operators still hold the network infrastructure, but have lost end user control. The third scenario defines mobile operators as end service providers, who do not control network anymore, and in the fourth scenario, the most pessimistic one, operators have lost the full control over all the elements (Monitor Deloitte, 2017). No matter which case happens, each of the scenarios triggers changes in the business model operators have nowadays.

A business model can be defined in various ways. In a simple and short way, a business model is described as the "way of doing business" or its "business concept" (Hamel, 2002; Voelpel, Leibold, Tekie \& Krogh, 2005). Campanovo and Pigneur (2003) define the business model as a detailed conceptualization of an enterprise's strategy at an abstract level, which serves as a base for the implementation of business processes. 
Ghezzi, Cortimiglia \& Franc (2015) assumed that external and internal changes influence the company's strategy and affect business model elements, as a result, strategic re-planning process should be triggered. New customer preferences also represent an opportunity for business model changes (Casadesus-Masanell \& Zhu, 2012).

Mobile operators can take different actions to empower innovation and stay competitive in the market:

- create a development centre (Rohrbeck, Thom \& Arnold, 2015)

- create partnership with OTT players (Bayen \& Ajadi, 2017; Xu \& Chen, 2015)

- charge OTTs mobile Internet access fee (Xu \& Chen, 2015).

When mobile operators innovate inside organization, the investment required is quite high and the approach is risky for operators as they do not have the necessary skills to launch such services (Sujata et al., 2015). Xu and Chen (2015) concluded in their research that for both mobile operators and OTT service providers the biggest profit on both sides could be achieved through cooperation strategy rather than charging OTTs access fee. Hung and Chou (2013) conclude that technological turbulence significantly and positively moderates the effect of inbound open innovation on firm performance. Competitive advantage is a key strategic element of open innovation (Ghezzi, Balocco \& Rangone, 2016). Creating networks with external organisations seem to offer flexibility, speed, innovation, and the ability to adjust smoothly to changing market conditions and new strategic opportunities (Dittrich \& Duysters, 2007; Schneider \& Spieth, 2013; Munir, Linaker, Wnuk, Runeson \& Regnell, 2017). The ability of the firm to maintain and develop external connections is the first critical enabler that explains higher levels of success (Sisodiya, Johnson \& Gregoire, 2013). Companies are trying to collaborate with startups and to transform them into engines of corporate innovation since the corporation has resources, scale, power, and the routines while a startup has promising ideas, organizational agility, the willingness to take a risk and aspirations for rapid growth (Weiblen \& Chesbrough, 2015).

Using external knowledge for product development might also mean using the input from customer so that the product can be developed and optimized according to user wishes. The customers' feedback has been an important part of product innovation in recent years (Bosch-Sijtsema \& Bosch, 2014; Schaarschmidt \& Kilian, 2014).

\section{Research Methodology}

The paper reviews the literature on market trends in the telecommunication industry and analyses new business models mobile operators are implementing. To answer the research questions various studies, reports, reviews, books, white papers, articles were analysed. Operators' strategy was analysed based on annual reports published by leading mobile operators. Statistical data were taken from respected institutions in telecommunication industry: International Telecommunication Unit (ITU), European Union statistical office (Eurostat), Republic of Serbia Regulatory Agency for Electronic Communication and Postal services (Ratel) and reports from global leaders in ICT solutions (Cisco, Ericsson). For every proposed business model, an example was given, and these were taken from mobile operator's official press releases.

\section{Telecommunications Market Trend}

The demand for mobile data services to watch videos, browse the Internet, and use applications have accelerated rapidly. One example of this trend is that at the end of the 1990s, the number of Internet users in the EU was around $15 \%$ of the population and only a fraction thereof used online shopping. Now, Internet penetration in this region has reached $85 \%$, and the number of online shoppers has increased to almost $60 \%$ (Eurostat, 2017a; Eurostat, 2017b). Mobile broadband subscriptions have grown by more than $20 \%$ annually in the last five years and are expected to reach 4.3 billion globally by the end of 2017 (ITU, 2017). Global mobile data traffic grew by an estimated 63\% in 2016 (Cisco, 2017). According to Ericsson (2017) traffic measurement for the period 2012-2017, in each quarter there was a strong growth in data traffic, while voice traffic was stagnating. It is anticipated that by the end of 2022 mobile broadband subscriptions will reach more than $90 \%$ of all mobile subscriptions. These data show that the telecommunication industry is shifting from an industry that was all about voice to one that is mostly about data. 
Today, almost half of global telecommunication revenue (48\%) comes from data, compared to only $22 \%$ five years ago (Vodafone, 2017). Global telecommunication revenues declined by 4\% between 2014 and 2015 (ITU, 2017). Mobile broadband prices, as a percentage of gross national income per capita, dropped by half between 2013 and 2016 (ITU, 2017). The study from (2017) has calculated that the consumer migration to OTT messaging services will cost network operators nearly $\$ 104$ billion this year, equivalent to $12 \%$ of their service revenues.

These statistics show that the demand for data services grew significantly in the past and will keep up with this trend. Mobile operators are constantly challenged with price erosion and increasing capacity demands. To follow the market trend, operators are forced to keep on investing in network infrastructure. On the other hand, having just good quality network for all the digital solutions will not be enough. Mobile operators nowadays are looking for ways to become the end to end service providers. Percentage of providers offering services such as video, music, cloud storage, location based services and etc. grew from 35\% in 2011 to 85\% in 2014 (Allot, 2014).

Annual reports published by leading telecommunications providers (Telekom Austria, 2017; Vodafone, 2017; Telenor, 2017) show that mobile operators have similar strategies: to be the best in the core business, to obtain network leadership, to expand their portfolio, to have the best customer experience and to offer digitalized services. Operators are working on a machine to machine communication solutions that include automotive, fleet management, smart cities, health and manufacturing. Cisco (2017) predicts that by 2021, M2M mobile connections will reach more than a quarter of total devices and connections. Mobile operators are preparing for the fifth-generation network. The $5 \mathrm{G}$ will enable a wide range of use cases for the massive Internet of Things. In 2022, the number of $5 G$ subscriptions is forecasted to reach more than 500 million (Ericsson, 2017).

Digitalisation trend boosts tendency for infrastructure investment. It is extremely complex, and it requires operational, organizational and business changes (Contreras et al., 2015). However, every technology progress so far required similar reorganisations and operators are familiar with these dynamic changes. By only improving the network infrastructure, the operator's revenue will hardly grow. Broadening product portfolio is a big challenge for mobile operators. To take advantage of digitalisation trend changes in business model are needed. In some cases operators are working on innovations on their own, but more frequently they create different development programmes through which they work with partners on creating new products.

\section{Mobile Operators Partnering with Other Organizations}

Innovation and creativity in the workplace have become increasingly important determinants of organizational performance, success, and longer-term survival (Anderson, Potocnik \& Zhou, 2014). Inbound open innovation or external knowledge sourcing refers to the practice of establishing relationships with external organisations or individuals with the purpose of accessing their technical or scientific competencies for improving internal innovation performance (Chiaroni et al., 2010). By pooling intellect in a system architecture, open invention and open coordination can produce superior products and services relative to those produced by a smaller number of minds huddled together in a single company (Chesbrough \& Appleyard, 2007). Operators can access external knowledge sources by various means of agreements involving individuals, companies and other organisations that possess the relevant knowledge to complement the operator's internal innovation.

\subsection{Mobile operators partnering with universities and R\&D institutions}

Almost every operator has some partnership with R\&D institutions and universities. By being in contact with R\&D institutions, they stay in touch with all the latest scientific achievements. In 2016, the Telekom Austria Group had research partnerships with the Vienna University of Technology, the Christian Doppler Laboratory for Wireless Technologies for Sustainable Mobility, the Christian Doppler Laboratory for Dependable Wireless Connectivity for the Society in Motion, and the Josef Ressel Centre for User-friendly Secure Mobile Environments (Telekom Austria, 2017). In collaboration with the Norwegian University of Science and Technology, Telenor will establish a lab within Artificial Intelligence and Big Data in Trondheim (Telenor, 2017).

\subsection{Mobile operators cooperating with startups}

Mobile operators can connect with startups in many different ways, depending on the amount of invested money and the level of collaboration (Bayen \& Ajadi, 2017). Once collaboration is established, startups can be an important source of innovation and growth. Companies create different development programmes 
through which startups receive support, funding, coaching, and co-location. Programmes allow operators to engage with a larger number of startups, to pursue multiple interesting approaches in parallel depending on the number of startups they work with. When working with operators, startups can get equipment, market access and industry expertise and can add a well-known brand name to their list of customer references after the completion of the joint project (Weiblen \& Chesbrough, 2015).

To maximise the chances of success, choosing which startup to work with and at what maturity stage is an important factor. To organise a competition is a common way for operators to start a collaboration with a startup. Mobile operators organise the competition usually by defining the category for solutions. Winners get short-term grant, but also a chance to continue working with the operator. Some competitions are held for public relations reasons rather than a real desire to engage in long-term partnerships. Also, startups sometimes focus only on seeking funding, not opportunities to collaborate (Bayen \& Ajadi, 2017). On the other hand, operators organise competitions to find startups they want to work with through some development programmes, incubators, accelerators. A1 Startup challenge is a competition that is held in Vienna, in which A1 is looking for a startup to work on developing innovative digital solutions (A1, 2015). Telefonica organised a competition to identify the innovative technological projects with the greatest potential in the world. It was a virtual race that could be joined by innovative projects and startups from around the world (Telefonica, 2016).

Another way for operators to connect with startups and start working with them is to invest in a technical hub. and invested in the project started by the European Commission, acceleration programme called the Startup Europe Partnership and a think tank called the European Digital Forum (Dawinderpal, 2014).

Once the startup or a partner is selected, operators can continue collaboration through different programmes and forms of partnerships. Corporate incubation has become an established means to commercialise corporate innovation (Weiblen \& Chesbrough, 2015). Mobile operators create a tech hub that can help startups develop their ideas. Operators give co-working space, financial investment, know-how and media relations. This is a way to offer internal operator knowledge and expertise and help the development of the invention. The program can last several months or a few years depending on the operator strategy. Operators define co-working conditions, and usually get a certain amount of startup equity. Telenor Accelerate (Hungary) is a short acceleration programme, lasting five months, which includes a series of workshops and mentoring sessions and access to Telenor infrastructure for testing and marketing opportunities among customers (Telenor, 2016a). A1 Start Up Campus is a programme that can last up to three years. Startups are given space to work on the campus and business consulting from dedicated A1 experts in the field of technics, marketing, sales, finance, PR, legal. A1 in return gets access to innovation and gets part of the equity share $(A 1,2015)$.

Operators can invest in a startup directly, through their founds. For example, A1 has invested $€ 600,000$ in Parkbob, a smart parking application. It combines real-time parking data with a database of parking regulations, linking these with geo-information to show where parking is allowed, how much it costs and where free parking spaces are in real time (European communications, 2016).

The mobile operator can make an equity investment in the startup partner resulting in a joint venture run by both entities. The MTN, one of Africa's largest telecom operators, has partnered with Rocket Internet and Millicom International Cellular to develop internet businesses in Africa through the Africa Internet Holding (AlH), a company dealing with e-commerce businesses across the African continent (MTN, Millicom and Rocket Internet each became 33.3\% shareholders in AIH) (MTN, 2013).

The mobile operator can make a deal with a startup to resell its product by putting it in the product portfolio. NavVis has developed a method for surveying building interiors with centimetre accuracy (it surveys building interiors by scanning them with lasers and simultaneously taking 360-degree panoramic photographs), and Deutsche Telekom has integrated this new system within its product portfolio (Deutsche Telekom, 2017). The mobile operator can acquire a startup to integrate it with its operations. This way the mobile operator can broaden its area of expertise and take a position in the new market or secure competences within the markets where they are already present. In 2016, Telenor Group bought $95 \%$ of Tapad company (Telenor, 2016b). This startup tracks data points across multiple screens (mobile, PC, TV) to gain a better sense of where consumers are going and what they are doing online. It then packages and sells that information to media buyers, brands and other advertisers to create better-targeted advertising. From the operator's point of view, this acquisition could improve understanding of customer behaviour and support building platform for other business areas. 
One operator can make different collaboration agreements with different startups. Startups can also collaborate with more than one operator. Mobile operators can also change the model of cooperation with startups as the product develops. One example of this is the cooperation between Parkbob and A1. Parkbob firstly participated in a startup competition organised by A1. After being selected, the startup employees moved to $A 1$ campus, where they worked together with $A 1$ experts on developing the application. Finally, after two years A1 decided to make the direct investment to support the further development of Parkbob. Weiblen \& Chesbrough (2015) discussed two different models of engaging with startups, a traditional one in which corporations have partial ownership over startup and an open business model in which there is no equity involved. The study showed that companies are evolving more lightweight models to engage with startups to accelerate their decision making and their ability to attract, support, and retain startups in large numbers. Nevertheless, the equity-based model gives a better financial performance in the case of success, it is a way to get deeper insights into new technologies or the strategic market for which the corporation is not able to provide a satisfying offering. The characteristics of these two types are shown in Table 1.

Table 1: Characteristics of collaboration models for outside innovation between mobile operator and startup

\begin{tabular}{|c|c|c|}
\hline & Corporate venturing & Startup program (no equity) \\
\hline Main goal & $\begin{array}{l}\text { Financial return, Insight and } \\
\text { influence }\end{array}$ & $\begin{array}{c}\text { Product innovation, First-mover } \\
\text { advantage }\end{array}$ \\
\hline Number of startups & Low & Medium \\
\hline Value capture & Equity stake & Product sales \\
\hline Organizational anchoring & $\begin{array}{c}\text { Separate venture capital arm, } \\
\text { board level }\end{array}$ & Separate innovation unit, $R \& D$ \\
\hline Time horizon of involment & Long term & Short term \\
\hline Admission of new startups & Due diligence & Open \\
\hline
\end{tabular}

Source: Weiblen \& Chesbrough, 2015

\section{Serbian Telecommunications Market and Operators Business Models}

There are three mobile operators in Serbia: Telekom Serbia (46.8\% market share in terms of number of subscribers), Telenor (31.2\%) and Vip mobile (22\%) (Ratel, 2017). The telecommunication market in Serbia is quite mature. From 2013 to 2016 the number of subscribers did not change much (9.2 million in 2013 and 9.09 million in 2016); $91.8 \%$ of inhabitants are using mobile phones; the percentage is a bit smaller for smartphones $-71.2 \%$ of inhabitants (Ratel, 2017). Regarding the network coverage of $4 \mathrm{G}$ signal mobile operators in Serbia are on track with the EU average. The average percentage of the $4 \mathrm{G}$ signal in the households in 2016 in EU was 84\%, and in Serbia, Vip mobile had the strongest coverage with 94.3\% (Ratel, 2017). The mobile communication industry in Serbia is getting to be data-centric, in the last five years, data traffic in average have grown by $46 \%$ yearly. The expansion of OTT messaging services and social media is noticeable in the statistics for SMS and MMS traffic. From 2015 to 2016 the number of sent SMS messages decreased by $12.8 \%$ and MMS by $17.3 \%$ (Ratel, 2017).

Statistical data show that the digitalisation trend has impacted the telecommunication market in Serbia, and accordingly mobile operators in Serbia are very active in innovation communities. Vip mobile has a collaboration with ICT Hub. One of their joint projects was hackathon organised with topic digitization of agriculture (ICT Hub, 2017). Vip mobile and ICT Hub also organised a competition "Vip loT Challenge". The task was to design and implement innovative Internet of Things (loT) solutions using narrowband technology (Cord, 2018). Telekom Serbia sponsors the Startit, an innovation center for IT. Additionally, they have created a programme, an MTS startup accelerator, through which they invested in the Startup academy (a programme that gathers and helps local startups) (MTS, 2018a). Telenor and MTS are both part of Digital Serbia Initiative (organization that stimulates digital innovation) (Digital Serbia Initiative, 2017).

Mobile operators in Serbia do not have their development centres. Still, they are broadening product portfolio and are offering new end to end services that are beyond their initial scope of offering pure data and voice traffic. In order to analyse operators' innovativeness in Serbia their product portfolios were analysed. It appears that mobile operators offer different services of cloud storage, applications for listening to music and watching TV, as well as some OTT services. The MTS offers software, created by Green soft, for automated agriculture production processes management (planning, tracking, maintaining agriculture processes, employee and 
machinery control) (MTS, 2018b). The "MyKi Touch" is a solution offered in collaboration with Alterco; it is a child watch designed to connect parents with a child, by allowing transmission of calls, text and voice messages as well as monitoring the exact position of a child (Vip mobile, 2017a). The Vip Enterprise Mobile Management is a solution for business customers developed in collaboration with the IBM that enables accessing company applications and data on the move in an efficient and secure way (Vip mobile, 2018). The "Vip mastalica" is a result of collaboration between Vip and Kreativni centar, it is an online collection of children stories (Vip mobile, 2017b). One very successful collaboration was between Vip mobile and startup Things solver; together they created a tool application that improved efficiency in radio network, it allowed a better radio capacity allocation and planning, optimization and foreseeing future user problems (Milovanovic, 2018).

Some of the mobile operators in Serbia are members of larger international groups (Vip mobile of A1 Telekom Austria group and Telenor Serbia of Telenor group) and as such can take advantage of all the innovation achievements created within the group inside their tech hub and in some cases to participate in them.

\section{Results and Discussion}

The first question paper investigated was how telecommunication market is changing and how mobile operators respond to it. The mobile communication industry in the last twenty years has been characterized by constant technology development from lower-generation network connectivity (2G) to higher-generation network connectivity (3G, 3.5G, and 4G or LTE) with each new technology resulting in faster, higher bandwidth and more intelligent networks. Today, mobile operators are preparing for the fifth-generation network that will enable a wide range of use cases for massive Internet of Things (higher traffic volume; indoor or hotspot traffic; traffic asymmetry; and spectrum, energy, and cost efficiency). Statistical data published by respected institutions in telecommunication industry such as ITU (2017) and Eurostat (2017a, 2017b) show that there is an increasing demand for data-centric services on one side (mobile broadband grows $20 \%$ annually) and operators revenue decline on the other (revenue declined 4\% between 2014 and 2015, and broadband prices dropped by half between 2013-2016). Results indicate that in order to respond to data traffic growth mobile operators need to invest in infrastructure and improve network capabilities. The need for data-centric services is rapidly growing and predictions by Ericsson (2017) and Cisco (2017) are that in the next five years data traffic will dominate mobile network. The revenue decline mobile operators are facing indicate that having a good quality network is not enough for generating satisfactory revenue and that mobile operators need to make changes in their respective portfolios and to offer more innovative data services. Therefore, to ensure their position as content providers, mobile operators need to expand their offer, beyond pure voice and data; they need to offer end to end services. Rarely do operators have enough knowledge, skills and finance to create new products internally which means they have to make some changes in the business model to empower innovation and generate new data services. These results have shown that, for mobile operators, innovation in the business model is as important as innovation in technology.

The second research question was what kind of partnerships mobile operators form with external organizations. To keep up with the newest trends and achievements, it is important for operators to be well informed, which is why many of them partner with R\&D institutes and universities. There are several benefits mobile operators can obtain when working with a startup: aachieve growth of core revenue, create or improve their image of innovative content provider, create a new revenue stream and reduce costs in some areas (Weiblen \& Chesbrough, 2015; Bayen \& Ajadi, 2017). One of the first and biggest challenges operators face is to choose the right startup to work with. Innovation hubs gather startups from different fields and as such are attractive for operators, that is why many operators choose to invest in hubs. A competition is also a popular way to select a partner. Competition and investment in local tech hub are collaboration programmes that do not require equity. Others can vary depending on the company's strategy and the depth, duration and success of collaboration between an operator and a startup. For instance, in the early stage on the inside development programme operators do not necessarily acquire equity, but as the product develops and the depth of cooperation increases, the operator usually acquires part of ownership over startup. This is the case in which the operator develops the product together with the startup; in case they notice a good business opportunity that is already developed and want to profit from it, they can sign a joint venture with the company, and resell the product. There is always a trade-off between these models; if collaboration is established at the early stage, the risk of product failure is higher but in case of success the profit is bigger; on the other hand, the probability of failure with already formed products is lower as well as profit margin. Another compromise is between the number of startups an operator can work with - the more investment they make in one startup, the less funds is left for other startups, but in case of success the profit will be higher. If operators work with several startups and solutions, the probability that at least one will succeed is higher but also the profit might be smaller. The summary of all collaboration models between startups and operators with listed examples is presented in Table 2 
Table 2: Collaboration models between mobile operator and startup

\begin{tabular}{|c|c|c|}
\hline \multicolumn{2}{|c|}{ Collaboration models } & Examples \\
\hline \multirow{3}{*}{ Partner/Startup selection } & Organise startup competition & $\begin{array}{c}\text { A1 startup competition, Telefonica } \\
\text { virtual race }\end{array}$ \\
\cline { 2 - 3 } & Invest in technical hub & $\begin{array}{c}\text { Telefónica, Orange and Startup Europe } \\
\text { Partnership, European Digital Forum }\end{array}$ \\
\hline \multirow{3}{*}{$\begin{array}{c}\text { Forms of partnerships } \\
\text { between Operators and } \\
\text { startups }\end{array}$} & Internal development centre & $\begin{array}{c}\text { Telenor Accelerate, } \\
\text { A1 Start up campus }\end{array}$ \\
\cline { 2 - 3 } & Make direct investment & A1\&Park Bob \\
\cline { 2 - 3 } & Sign joint venture & MTN\&AlH \\
\cline { 2 - 3 } & Content reselling & Deutche Telekom\&NavVis \\
\cline { 2 - 3 } & M\&A & Telenor\&Tapad \\
\hline
\end{tabular}

Source: A1, 2015; Dawinderpal, 2014; Deutsche Telekom, 2017; European communications, 2016; MTN, 2013; Telefonica, 2016; Telenor, 2016a; Telenor, $2016 b$

Reports published by leading mobile operators (Telekom Austria, 2017; Telenor, 2017; Vodafone, 2017;) demonstrate that mobile operators have awareness about the market trend that generate constant need for new services, and that they are trying to raise their innovation activities in collaboration with different partners, which confirms that open innovation is the way to enforce internal innovation and create new products.

External knowledge and knowledge from other industries cannot only complement the existing expertise in the company but can also broaden the perspective for new ideas and approaches. Working with dynamic, adoptive and fresh motivated experts like the ones working in a startup can lead to generating some new ideas and solutions that operators were not even aware of before the collaboration process. One of the examples for this is a very successful collaboration between Things solver startup and Vip mobile (Milovanovic, 2018). Data mining and radio access optimization know how was combined and as a result, a tool that allows a better radio capacity allocation and planning, optimization and foreseeing future user problems was created. This tool made financial savings for the company, but it was also the first product that was created inside the company and could be sold to other operators.

The telecommunication market in Serbia is characterized by constant growth of data traffic, reduced demand for SMS/MMS and broad operator's portfolio with a range of innovative services they have created in collaboration with different partners (children's watch, cloud storage, solution for data security, agriculture management tool). Operators also tend to increase innovation activities by connecting with a local hub (Vip mobile and ICT Hub, Telekom and Telenor with Startit). These results answer the third research question that telecommunication market in Serbia is changing in the same direction as in other developed countries.

Conslusion

The paper shows the business models mobile operators are using to broaden their respective portfolios and remain competitive in the market and it highlights the importance of business model innovation in the telecommunication industry. Mobile operators have a clear strategy for technical improvements. Statistical data show growth of data traffic in the past years, and predictions are that this trend will continue. To respond to an increasing market need for data consumption, operators are focused on modifying their infrastructure and are working on goals such as network virtualisation, M2M and the fifth generation network. Improving technical performances of the network is imperative since it is dictated by the market trend. Nevertheless, if operators are offering only good quality network without OTT services, financial achievements will not be satisfactory. The revenue of mobile operators is threatened by the OTT service providers and to respond to this mobile operators need to expand their portfolios and to offer end to end services. To achieve this, they should modify their business model which shows that innovation in business model is as important as innovation in technology.

The topic of open business models is widely present in literature. However, there were not so many researches dealing with their application to the telecommunication industry (Xu \& Chen, 2015; Dittrich \& Duysters, 2007; Weiblen \& Chesbrough, 2015). Analysis of different reports and offers has shown that mobile operators are aware of the market trend and are already working on empowering their innovation processes. Operators make different partnerships with various 
institutions such as R\&D institutes, universities and startups. Operators create different development programmes through which they offer support, funding, coaching, and co-location. Programmes allow them to engage with a larger number of partners and to work on multiple interesting approaches in parallel. Mobile operators can connect with startups in several ways, depending on the amount of invested money and the level of collaboration. This confirms that operators use open business models to increase innovation activities.

Mobile communication market in Serbia is getting influenced by digitalisation trend. This has been proven by statistical data showing growth in the data traffic, decrease in SMS and MMS traffic and high investments in data network. Portfolios of mobile operators in Serbia show that they are applying new business models to create new products. They invest in innovation hubs, organise startup competitions, invest in startups and resell content of other companies.

No publication dealing with open business models mobile operators apply in Serbia was found in literature. This area should be examined in more detail. For further research primary data should be collected from operators, to investigate into their experience in cooperating with partners and creating offers that are out of their scope. Since the telecommunication market in Serbia is changing in the same direction as in other developed countries, the results can be generalized to apply to other markets as well.

The paper analyses possible models which mobile operators can implement to empower their innovation activities. This study can help managers and directors to refine internal innovation processes and provides information about possible

\section{REFERENCES}

[1] Allot. (2014). App-Centric Operators on the Rise - Allot Mobile trends 2014. Retrieved from http://investors.allot.com/releasedetail.cfm?releaseid $=859652$

[2] Anderson, N., Potocnik, K., \& Zhou, J. (2014). Innovation and Creativity in Organizations: A State-of-theScience Review, Prospective Commentary, and Guiding Framework. Journal of Management, 40(5), 1297 -1333. DOI:10.1177/0149206314527128

[3] Asimakopoulos, G., \& Whalley, J. (2017). Market leadership, technological progress and relative performance in the mobile telecommunications industry. Technological Forecasting and Social Change, 123, 57-67. DOI:10.1016/j.techfore.2017.06.021

[4] Aspara, J., Lamberg, J., Laukia, A., \& Tikkanen, H. (2013). Corporate Business Model Transformation and Inter-Organizational Cognition: The Case of Nokia. Long Range Planning, 46(6), 459-474. DOI:10.1016/j.Irp.2011.06.001

[5] Bayen, M. \& Ajadi, S. (2017). Building Synergies: How Mobile Operators and Startups Can Partner for Impact in Emerging Markets. Retrieved from https://www.gsma.com/mobilefordevelopment/programme/ecosystem-accelerator/buildingsynergies-how-mobile-operators-and-start-ups-can-partner-for-impact-in-emerging-markets

[6] A1. (2015). A1 startup campus. Retrieved from https://www.a1startup.net/

[7] BEREC - Body of European Regulators for Electronic Communications. (2016). BEREC Report on OTT services. Retrieved from http://berec.europa.eu/eng/document_register/subject_matter/berec/reports/5751-berec-report-onott-services

[8] Bosch-Sijtsema, P., \& Bosch, J. (2014). User Involvement throughout the Innovation Process in HighTech Industries. Journal of Product Innovation Management, 32(5), 793-807. DOI:10.1111/jpim.12233

[9] Campanovo, G. and Pigneur, Y. (2003), 'Business model analysis applied to mobile business', Proceedings of the 5th International Conference on Enterprise Information Systems, Angers, 23-26 April.

[10] Casadesus-Masanell, R., \& Zhu, F. (2012). Business model innovation and competitive imitation: The case of sponsor-based business models. Strategic Management Journal, 34(4), 464-482. DOI:10.1002/smj.2022

[11] Cheng, C. C., \& Huizingh, E. K. (2014). When Is Open Innovation Beneficial? The Role of Strategic Orientation. Journal of Product Innovation Management, 31(6), 1235-1253. DOI:10.1111/jpim.12148

[12] Chesbrough, H. (2006) Open Business Models: How to thrive in the New Innovation Landscape. Harvard Business School Press, Boston. DOI:10.1111/j.1540-5885.2008.00309_1.x

[13] Chesbrough, H. (2010). Business Model Innovation: Opportunities and Barriers. Long Range Planning, 43(2-3), 354-363. doi:10.1016/j.Irp.2009.07.010

[14] Chesbrough, H. W., \& Appleyard, M. M. (2007). Open Innovation and Strategy. California Management Review, 50(1), 57-76. DOI:10.2307/41166416 
[15] Chiaroni, D., Chiesa, V., \& Frattini, F. (2010) Unravelling the process from closed to open innovation: Evidence from mature, asset-intensive industries. R\&D Management 40(3), 222-245. DOI:10.1111/j.1467-9310.2010.00589.x

[16] Cisco. (2017). Cisco Visual Networking Index: Global Mobile Data Traffic Forecast Update, 20162021. Retrieved from https://www.cisco.com/c/en/us/solutions/collateral/service-provider/visual-networking-indexvni/mobile-white-paper-c11-520862.pdf

[17] Contreras, L. M., Doolan, P., Lønsethagen, H., \& López, D. R. (2015). Operational, organizational and business challenges for network operators in the context of SDN and NFV. Computer Networks, 92, 211-217. DOI:10.1016/j.comnet.2015.07.016

[18] Cord. (2018). Open Applications for "Vip loT Challenge". Retrieved from http://cordmagazine.com/news/open-applications-for-vip-iot-challenge/

[19] Dawinderpal, S. (2014). Telefonica and Orange grow European startups | Telecomscom. Retrieved from http://telecoms.com/216432/telefonica-and-orange-grow-european-startups/

[20] Deutsche Telekom. (2017). Deutsche Telekom's "TechBoost" startups program kicks off. Retrieved from https://www.telekom.com/en/media/media-information/archive/deutsche-telekom-techboost-startupsprogram-kicks-off-488460

[21] Digital Serbia Initiative. (2017). Retrieved from https://www.dsi.rs/en/about-us/

[22] Dittrich, K \& Duysters, G. (2007). Networking as a Means to Strategy Change: The Case of Open Innovation in Mobile Telephony. Journal of Product Innovation Management, 24(6), 510-521. DOI:10.1111/j.1540-5885.2007.00268.x

[23] Ericsson. (2017). Ericsson mobility report. Retrieved from https://www.ericsson.com/assets/local/mobility-report/documents/2017/ericsson-mobility-report-june2017.pdf

[24] European communications. (2016). Telekom Austria makes first investment in startup from its own incubator. Retrieved from https://www.eurocomms.com/industry-news/12211-telekom-austria-makesfirst-investment-in-startup-from-its-own-incubator

[25] Eurostat. (2017a). Internet purchases by Individuals - Eurostat. Retrieved from http://ec.europa.eu/eurostat/web/products-datasets/-/isoc_ec_ibuy

[26] Eurostat. (2017b). Level of Internet access - households - Eurostat. Retrieved from http://ec.europa.eu/eurostat/web/products-datasets/-/tin00134

[27] Hamel, G., 2002. Leading the Revolution: How to Thrive in Turbulent Times by Making Innovation aWay of Life. Harvard Business School Press, Boston, MA.

[28] Hung, K., \& Chou, C. (2013). The impact of open innovation on firm performance: The moderating effects of internal R\&D and environmental turbulence. Technovation, 33(10-11), 368-380. DOI:10.1016/j.technovation.2013.06.006

[29] Foss, N. J., \& Saebi, T. (2016). Fifteen Years of Research on Business Model Innovation. Journal of Management, 43(1), 200-227. DOI:10.1177/0149206316675927

[30] Gerpott, T. J., \& Meinert, P. (2016). The impact of mobile Internet usage on mobile voice calling behavior: A two-level analysis of residential mobile communications customers in Germany. Telecommunications Policy, 40(1), 62-76. DOI:10.1016/j.telpol.2015.09.004

[31] Ghezzi, A., Cortimiglia, M. N., \& Frank, A. G. (2015). Strategy and business model design in dynamic telecommunications industries: A study on Italian mobile network operators. Technological Forecasting and Social Change, 90, 346-354. DOI:10.1016/j.techfore.2014.09.006

[32] Ghezzi, A., Balocco, R., \& Rangone, A. (2016). The Open Innovation - Strategy nexus: findings from the Mobile Telecommunications Industry. Management Research Review, 39(5), 569-598. DOI:10.1108/mrr02-2014-0040

[33] ICT Hub. (2017). Digitalizacija poljoprivrede kao tema prvog AgTech hakatona u Srbiji. Retrieved from http://startup.icthub.rs/digitalizacija-poljoprivrede-kao-tema-prvog-agtech-hakatona-u-srbiji/

[34] ITU - International Telecommunication Union. (2017). ICT Facts and Figures 2017. Retrieved from http://www.itu.int/en/ITU-D/Statistics/Pages/facts/default.aspx

[35] Juniper research. (2017). PR Newswire. Retrieved from http://www.prnewswire.com/newsreleases/consumer-migration-to-ott-services-to-cost-mobile-operators-more-than-100bn-in-lost-revenue s-this-year-610109315.html

[36] Lutilsky, D. \& Ivic, M. (2016). Influence of OTT Service Providers on Croatian Telecomunication Market. 39th International Convention on Information and Communication Technology, Electronics and Microelectronics (MIPRO). Opatija, Croatia: IEEE. DOI:10.1109/MIPRO.2016.7522233

[37] Milovanovic, M. (2018). Success Formula: Science, Business and Programming. Retrieved from https://thingsolver.com/success-formula-science-business-programming/ 
[38] Monitor Deloitte. (2017). To be or not to be The future of telco business model. Retrieved from from: https://www2.deloitte.com/content/dam/Deloitte/de/Documents/technology-mediatelecommunications/Deloitte-TMT-Telco-2030.pdf

[39] MTN. (2013). MTN partners to bring e-commerce services to African markets. Retrieved from https://www.mtn.com/en/mtn-group/press-and-insights/press-releases/Pages/h-press-releasedetail.aspx?queryString $=120$

[40] MTS. (2018a). Telekom Srbija invests in promising technological entrepreneurs. Retrieved from https://www.mts.rs/eng/news/2497/telekom-srbija-invests-in-promising-technolog

[41] MTS. (2018b). Agrolife retrieved from https://www.mts.rs/poslovni/ICT-servisi/cloud/agrolife

[42] Munir, H., Linåker, J., Wnuk, K., Runeson, P., \& Regnell, B. (2017). Open innovation using open source tools: A case study at Sony Mobile. Empirical Software Engineering, 23(1), 186-223. DOI:10.1007/s10664-017-9511-7

[43] Ratel. (2017). Pregled trzista telekomunikacija I postanskih usluga u republici Srbiji u 2016. godini. Retrieved from http://www.ratel.rs/trziste/pregledi trzista.230.html

[44] Rohrbeck, R., Thom, N., \& Arnold, H. (2015). IT tools for foresight: The integrated insight and response system of Deutsche Telekom Innovation Laboratories. Technological Forecasting and Social Change, 97, 115-126. doi:10.1016/j.techfore.2013.09.015

[45] Saebi, T., \& Foss, F. (2014). Business models for open innovation: Matching heterogenous open innovation strategies with business model dimensions. European Management Journal, 33(3), 201-213. DOI:10.1016/j.emj.2014.11.002

[46] Schaarschmidt, M., \& Kilian, T. (2014). Impediments to customer integration into the innovation process: A case study in the telecommunications industry. European Management Journal, 32(2), 350-361. DOI:10.1016/j.emj.2013.04.004

[47] Schneider, S., \& Spieth, P. (2013). Business Model Innovation: Towards An Integrated Future Research Agenda. International Journal of Innovation Management, 17(01), 1340001. DOI:10.1142/s136391961340001x

[48] Sisodiya, S. R., Johnson, J. L., \& Grégoire, Y. (2013). Inbound open innovation for enhanced performance: Enablers and opportunities. Industrial Marketing Management, 42(5), 836-849. DOI:10.1016/j.indmarman.2013.02.018

[49] Sujata, J., Sohag, S., Tanu, D., Chintan, D., Shubham, P., \& Sumit, G. (2015). Impact of Over the Top (OTT) Services on Telecom Service Providers. Indian Journal of Science and Technology, 8(4), 145160. DOI:10.17485/ijst/2015/v8iS4/62238

[50] Telekom Austria. (2017). Annual Reports |Telekom Austria Group. Retrieved from https://www.telekomaustria.com/en/ir/annual-reports

[51] Telefonica. (2016). Telefónica Open Future_launches competition to identify the innovative technological projects with the greatest potential in the world. Retrieved from https://www.telefonica.com/en/web/press-office/-/telefonica-open-future_launches-competition-toidentify-the-innovative-technological-projects-with-the-greatest-potential-in-the-world

[52] Telenor. (2016a). Telenor accelerate - where success begin. Retrieved from https://www.telenor.hu/accelerate

[53] Telenor. (2016b). Telenor to acquire marketing technology firm Tapad - Telenor Group. Retrieved from https://www.telenor.com/media/press-release/telenor-to-acquire-marketing-technology-firm-tapad/

[54] Telenor. (2017). Annual report - 2016. Retrieved from https://www.telenor.com/wpcontent/uploads/2017/03/Annual-Report-2016-Q-960dfcfa007ceee404c193b48ad20cff.pdf

[55] Vip mobile. (2017a). Vip mobile-MyKi Touch. Retrieved from https://www.vipmobile.rs/privatni/mobilni_uredjaji/detalji?device $=278$

[56] Vip mobile. (2017b). Mastalice-audio-stories that encourage children's imagination. Retrieved from https://www.vipmobile.rs/press-centar/mastalice--audio-price-koje-podsticu-decjumastu?slug=mastalice-audio-price-koje-podsticu-decju-mastu

[57] Vip mobile. (2018). Vip mobile-EMM. Retrieved from https://www.vipmobile.rs/poslovni/poslovna_resenja/vip_emm

[58] Vodafone. (2017). Vodafone Group Plc Annual Report 2016. Retrieved from https://www.vodafone.com/content/annualreport/annual_report17/index.html

[59] Voelpel, S., Leibold, M., Tekie, E., \& Krogh, G. V. (2005). Escaping the Red Queen Effect in Competitive Strategy:. European Management Journal, 23(1), 37-49. doi:10.1016/j.emj.2004.12.008

[60] Wang, J., Lai, J., \& Chang, C. (2016). Modeling and analysis for mobile application services: The perspective of mobile network operators. Technological Forecasting and Social Change, 111, 146-163. DOI:10.1016/j.techfore.2016.06.020

[61] Weiblen, T., \& Chesbrough, H. (2015). Engaging with Startups to Enhance Corporate Innovation. California Management Review, 57(2), 66-90. DOI:10.1525/cmr.2015.57.2. 
[62] Xu, X., \& Chen, R. (2015). Competition, Cooperation, and Pricing: How Mobile Operators Respond to the Challenge of Over-The-Top. International Journal of Marketing Studies, 7(6), 1. doi:10.5539/ijms.v7n6p1

[63] Yang, C., Trimi, S., \& Lee, S. (2016). Effects of telecom service providers' strategic investments on business performance. Industrial Management \& Data Systems, 116(5), 960-977. DOI:10.1108/imds-082015-0350

Received: 2018-01-03 Revisions requested: 2018-03-18 Revised: 2018-09-12 (3 revisions)

Accepted: 2018-09-19

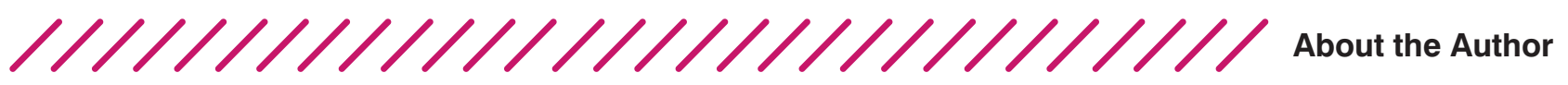

\author{
Jovana Mihailovic \\ Vip mobile d.o.o., Belgrade, Serbia \\ e-mail: j.mihailovic@vipmobile.rs
}

Jovana Mihailovic, MSc, works with the Vip mobile and has more than five years of experience in the mobile communication industry. She finished a double degree master

programme in telecommunications at Karlsruhe Institute of Technology (Karlsruhe,

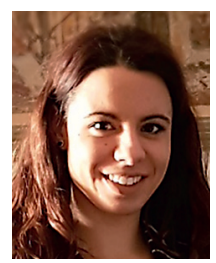

Germany) and Polytechnical University of Catalonia (Barcelona, Spain). She obtained a

BSc in electrical engineering at the University of Belgrade, School of Electrical

Engineering. Jovana is a PhD student at the at the University of Belgrade, Faculty of

Organizational Sciences. Her current research and area of interest include open

innovation, open business models and agile methodologies in telecommunications. 